Original Research

\title{
In Vitro Antioxidant, Antidiabetic, Antimicrobial and Cytotoxic Studies of Caragana ambigua Stocks
}

\author{
Faryal Rubab, Saiqa Ishtiaq* \\ Punjab University College of Pharmacy, University of the Punjab, Lahore-54000, Pakistan
}

Received: 22 March 2021

Accepted: 2 July 2021

\begin{abstract}
Caragana ambigua stocks has been used in different traditional medicinal systems to treat diabetes and various stomach disorders. It has also been utilized for the nourishment and the regulation of blood flow. However, the biological profile and phytochemistry of this plant still need to be explored. The objective of current study is to probe therapeutic potential of Caragana ambigua. Methanolic extract of Caragana ambigua and its five fractions namely, n-hexane, chloroform, ethyl acetate, n-butanol and aqueous were evaluated for in vitro antioxidant (total phenolic and flavonoid content, DPPH assay, DNA protection assay), antidiabetic ( $\alpha$-amylase inhibition assay), antimicrobial (disc diffusion assay) and cytotoxicity studies (XTT assay and RBC's cellular membrane protection assay). Amongst the investigated fractions and methanolic extract, the highest phenolic content $(80 \mathrm{mg} / \mathrm{g}$ gallic acid equivalent) was observed in $n$-hexane and chloroform fraction whilst the maximum flavonoid content (18 mg/g quercetin equivalent) and the most significant $(\mathrm{p}<0.05) \alpha$-amylase enzyme inhibition was also displayed by $\mathrm{n}$-hexane fraction $\left(\mathrm{IC}_{50}=252.2 \pm 1.08 \mu \mathrm{g} / \mathrm{mL}\right)$. Whereas the significant $(\mathrm{p}<0.05) \mathrm{DPPH}$ inhibition was found in butanol fraction $\left(\mathrm{IC}_{50}=76.44 \pm 1.50 \mu \mathrm{g} / \mathrm{mL}\right.$ ). Moreover, butanol fraction at $200 \mu \mathrm{g} / \mathrm{mL}$ was also observed to protect the DNA from nicking. Methanolic extract and its analyzed fractions also exhibited cytotoxicity potential against human breast cancer and T-lymphoblastic leukemia cell lines. However, significant $(\mathrm{p}<0.05)$ dose dependent inhibitory effects on cell growth were observed against T-lymphoblastic leukemia cell lines where the maximum cytotoxicity $(7.533 \pm 0.430 \%)$ was exhibited by $n$-hexane fraction. No substantial findings were obtained in case of antimicrobial activity against the tested strains. Lastly, hemolytic potential was found to be in the safe range. Thus, it can be concluded that Caragana ambigua can be exploited as an alternative approach to treat diabetes, cancer and other diseases by reducing oxidative stress.
\end{abstract}

Keywords: Caragana ambigua, $\alpha$-amylase inhibitor, cytotoxic, antioxidant

*e-mail: saiqa.pharmacy@pu.edu.pk 


\section{Introduction}

Caragana is a member of family Fabaceae which is comprised of approximately 100 species. Most members of this genus are shrubs which are widely distributed throughout the region of Euro-Asia. In Traditional Chinese Medicine (TCM), species belonging to the genus Caragana have been used in the prevention of fever, cough, cancer, dizziness, inflammation, hypertension, rheumatism, arthritis, strain-induced exhaustion, nose bleed, asthma and neuralgia [1, 2]. Some members of Caragana are still underexploited in terms of their chemical and biological potential, one such member is Caragana ambigua stocks ( $C$. ambigua). In TCM, C. ambigua has been used in multifunctional activities like blood nourishment and regulation of blood flow [3]. Conventionally, juice obtained from the whole plant of C. ambigua has been used to treat diabetes mellitus in south-west Pakistan [4]. It has also been used as fodder by the native community of Baluchistan (a major province of Pakistan) to fortify the digestive tract where it is also known by the vernacular name of "Makhi" $[5,6]$. This species incorporates high phenolic contents along with alkaloids, saponins and tannins [7]. Furthermore, $C$. ambigua seeds encompass a unique peptide named as Caragana ambigua seed peptide (CSP) which has antioxidant potential. The exclusive peptide has the ability to slow down lipid oxidation rates and protect a variety of polyunsaturated fatty acids from autooxidation [8].

A more recent study analyzed $C$. ambigua through liquid chromatography mass spectrometry. This investigation proposed 16 and 26 different secondary metabolites in methanolic and ethyl acetate extracts, respectively. Most of the characterized compounds belong to flavonoids, alkaloids, saponins, coumarins and terpenoids. The secondary metabolites found in noteworthy abundance include robinin, glyceollin I, citbismine C, jujubasaponin IV, phellamurin, texasin, psoralidin oxide, phellodensin D, phellatin, kaempferide, and aurmillone. n-Hexane extract of C. ambigua was found to have the most auspicious inhibition of acetylcholinesterases, $\alpha$-amylase and $\alpha$-glucosidase enzymes while ethyl- acetate extract was the most effective inhibitor of tyrosinase enzyme [3].

The present work has been intended to discover the in vitro antioxidant, antidiabetic, antimicrobial and cytotoxic activities of $C$. ambigua. To the best of our knowledge, the hemolytic activity towards healthy human erythrocytes, cytotoxicity against cancer cell lines and antimicrobial potential of $C$. ambigua have been reported for the first time in this study.

\section{Materials and Methods}

\author{
Plant Collection
}

The aerial parts of $C$. ambigua were collected in May 2016 from Ziarat, Pakistan. The voucher number GC.Herb.Bot.3446 was assigned and submitted to the Herbarium of GC University, Lahore, Pakistan.

\section{Preparation of Plant Extracts and Fractions}

Collected plant material was washed with water and dried in the shade. One kilogram of dried plant material was then pulverized using a mechanical mill. The powdered sample was subjected to cold maceration using $2.5 \mathrm{~L}$ of methanol for seven days. The methanolic extract of C. ambigua (CA-M) was subsequently dried using rotary evaporator under reduced pressure. The residue thus obtained was suspended in water $(50 \mathrm{~mL})$ and afterwards fractionated with different solvents of increasing polarity i.e., n-hexane $(250 \mathrm{~mL})$, chloroform $(250 \mathrm{~mL})$, ethyl acetate $(250 \mathrm{~mL})$, and n-butanol $(250 \mathrm{~mL})$. The different fractions of C. ambigua plant namely, n-hexane (CA-H), chloroform (CA-C), ethylacetate (CA-E), n- butanol (CA-B) and water (CA-Aq) were dried using rotary evaporator and stored at $-20^{\circ} \mathrm{C}$ [9].

\section{In-vitro Antioxidant Activities}

\section{Total Phenolic Content (TPC)}

Following the method mentioned by Chandra et al., 2014, TPC of CA-M extract and its fractions was determined by utilizing Folin-Ciocalteu (FC) reagent. Shortly, $0.2 \mathrm{~mL}$ of the sample was mixed with water $(0.6 \mathrm{~mL})$. The obtained mixture was consequently subjected to the addition of $0.2 \mathrm{~mL}$ of FC reagent. After five minutes, sodium carbonate $(1 \mathrm{~mL})$ was added to the reaction mixture. Final volume was made up to three milliliters by dilution with water and allowed to keep in dark for 30 minutes. The absorbance was recorded

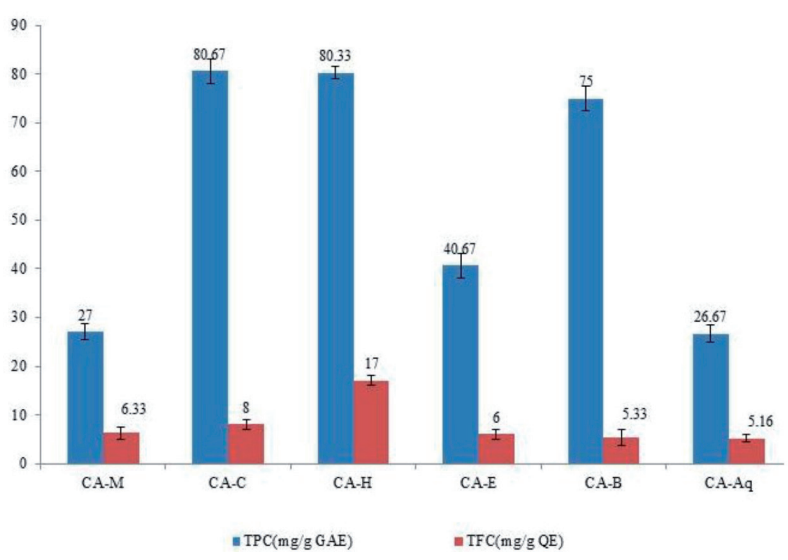

Fig.1. TPC and TFC of CA-M extract and its fractions. 
at $765 \mathrm{~nm}$ for all the samples employing UV-Vis spectrophotometer against reagent blank. The phenolic content was measured as gallic acid equivalent (GAE/g) of dry plant material. All determinations were carried out in triplicates [10].

\section{Total Flavonoid Content (TFC)}

For the evaluation of TFC of CA-M extract and its fractions, aluminum chloride colorimeter method was applied. Quercetin was used as the standard drug. Stock solution was prepared by dissolving five milligrams of quercetin in methanol $(1 \mathrm{~mL})$ while standard solution of quercetin was prepared by serial dilutions at different concentrations $(10-120 \mu \mathrm{g} / \mathrm{mL})$. By using two percent of aluminum chloride $(0.6 \mathrm{~mL})$, standard quercetin solution $(0.6 \mathrm{~mL})$ and plant samples were mixed separately. All samples were incubated for 60 minutes in the dark. After incubation, the absorbance was measured at $420 \mathrm{~nm}$ through UV-Vis spectrophotometer. Using the calibration curve, TFC in all the samples was calculated and expressed as quercetin equivalence $(\mathrm{QE} / \mathrm{g})$ of dry plant material. All determinations were carried out in triplicates [10].

\section{Free Radical Scavenging Activity (DPPH)}

Antioxidant potential of CA-M extract and its fractions was evaluated by applying DPPH assay. Ascorbic acid was taken as standard (positive control) whereas methanol was added to DPPH solution to achieve the concentration of $0.004 \% \mathrm{w} / \mathrm{v}$. A range of different concentrations $(10,20,40,60,80$ and $100 \mu \mathrm{g} / \mathrm{mL}$ ) of standard solutions and all the samples from extract and fractions were prepared in methanol. Two milliliters of DPPH solution were required for every two milliliters of sample mixture. After that, all samples were left in dark for 30 minutes prior to UV-Vis spectrophotometry at $517 \mathrm{~nm}$. Percentage inhibition of DPPH was measured by applying equation given below. $\mathrm{IC}_{50}$ was determined from plotted graph by comparing inhibition rate with sample concentrations [11].

$$
\text { Inhibition }(\%)=\left[\frac{\mathrm{A}-\mathrm{B}}{\mathrm{A}}\right] \times 100
$$

...where, $\mathrm{A}=$ Absorbance of control (DPPH+ methanol), $\mathrm{B}=$ Absorbance of sample extract or standard.

\section{Determination of DNA Protection Activity}

Fenton's reagent generates hydroxyl radicals that induce devastating effects on super coiled human DNA. Therefore, CA-M extract and its fractions were studied to rule out its protective efficacy against detrimental effects of hydroxyl radicals. By mixing human DNA
$(0.3 \mathrm{~mL})$ and Fenton's reagent $(10 \mu \mathrm{L})$, reaction mixture was prepared. Fenton's reagent was comprised of $80 \mathrm{mM} \mathrm{FeCl}, 30 \mathrm{mM} \mathrm{H}_{2} \mathrm{O}_{2}$ and $50 \mathrm{mM}$ ascorbic acid. After that, test samples were also added to the reaction mixture. Subsequently, distilled water was added to achieve the volume up to $20 \mu \mathrm{L}$. After incubation of reaction mixture for 30 minutes, bromophenol blue dye $(0.25 \%$ in $50 \%$ glycerol $)$ was added. Later, loading of $20 \mu \mathrm{L}$ of reaction mixture was accomplished in agarose gel prepared as $0.5 \mathrm{~g}$ of agarose in $50 \mathrm{~mL}$ of $1 \times \mathrm{TBE}$ buffer. Following staining with ethidium dibromide, running of gel electrophoresis was accomplished for an hour at 100 v. Gel Documentation system was used to visualize the human DNA [12].

\section{In-vitro $\alpha$-amylase Inhibitory Activity}

In-vitro antidiabetic potential of CA-M extract and its fractions was evaluated by using $\alpha$-amylase enzyme inhibition assay following the method described by Wikramaraatne et al., 2016. Antidiabetic drug acarbose served as positive control. Plant sample/standard solutions of different concentrations were taken separately in a test tube. Subsequently, $\alpha$-amylase solution $(200 \mu \mathrm{L})$ was added and incubated for 10 minutes at $30^{\circ} \mathrm{C}$. Afterwards, starch solution $(200 \mu \mathrm{L})$ was added in all the aliquots and placed in incubator for three minutes. $\alpha$-Amylase activity of reaction mixture was terminated by adding $200 \mu \mathrm{L}$ of DNS (3,5-Dinitrosalicylic acid) reagent in all the aliquots followed by heating on a water bath at $85^{\circ} \mathrm{C}-90^{\circ} \mathrm{C}$ for about eight minutes. After heating, all the aliquots were removed from water bath and allowed to cool in ice water. Finally, all the aliquots were diluted with five milliliters of water. Absorbance was recorded at $540 \mathrm{~nm}$ employing UV-Vis spectrophotometer. By replacing plant samples with buffer $(200 \mu \mathrm{L})$, sample blank was prepared. Following formula was applied to calculate percentage inhibition of plant extract and fractions against $\alpha$-amylase. $\mathrm{IC}_{50}$ was determined from plotted graph between percentage inhibition and sample concentrations [13].

$(\%) \alpha-$ Amylase Inhibition $(\%)=\left[\frac{\text { Absorbance }(\text { control })-\text { Absorbance(Sample })}{\text { Absorbance }(100 \% \text { control })}\right] \times 100$

\section{Antimicrobial Activity}

Standard bacterial strains of Escherichia coli (ATCC 8739), Psuedomonas aeruginosa (ATCC 9027), Staphylococcus aureus, Salmonella typhimurium (ATCC 6538) and Staphylococus epidermidis (ATCC 12228) were selected for the evaluation of antibacterial potential of CA-M extract. Antifungal activity was determined by using standard strains of Candida albicans (ATCC 10231), Aspergillus brasiliensis (ATCC 16404), and Saccharomyces cerevisiae (ATCC 9763). 


\section{Disc Diffusion Method}

Disc diffusion method was applied to study antimicrobial potential of CA-M extract. All the samples were dissolved in $10 \%$ DMSO. Different concentrations $(25 \%, 50 \%, 100 \%)$ of CA-M were impregnated on discs (6 $\mathrm{mm}$ diameter). Disc loaded with pure DMSO only, served as negative control. For positive control, discs loaded with ciprofloxacin and eberconazole $(100 \mu \mathrm{L} /$ disc $)$ were utilized for bacteria and fungi, respectively. All the discs were transferred onto the inoculated agar plates aseptically. For bacteria, plates were incubated for 24 hours at $37^{\circ} \mathrm{C}$ while plates with fungi were kept in incubator at $28^{\circ} \mathrm{C}$ for 72 hours. After incubation period, all plates were observed for the formation of zone of inhibition. Test was carried out in triplicates [14].

\section{In vitro Cytotoxicity Studies}

\section{XTT Assay}

Gibco RPMI-1640 medium (Invitrogen, Darmstadt, Germany) was used to grow two cell lines i.e., human breast cancer (MDA-MB-231) and T-lymphoblastic leukemia (CCRF-CEM). To support cell growth $10 \%$ fetal bovine serum was purchased from PAA Laboratories (Pasching, Austria). Streptomycin, $2 \mathrm{mM}$ of L-glutamine and $1 \%$ penicillin were added to the culture media. Five percent humidified $\mathrm{CO}_{2}$ and $37^{\circ} \mathrm{C}$ temperature was maintained for incubation of these cell cultures (Thermo Fisher Scientific Inc., Vienna, Austria). Cultures at approximately $90 \%$ confluency were routinely split in $25 \mathrm{~cm}$ culture flask at ratio (1:5). The 96-well plates were filled with MDA-MB-231 cells at density of 5000 cells per well while 10000 cells of CCRF-CEM per well. Cells were incubated with the plant samples at different concentrations $(5,10$ and $50 \mu \mathrm{g} / \mathrm{mL}$ ). After incubation, XTT reagent was added and incubated again for 1.5 hours. A Micro-plate Reader (Hidex ${ }^{\circledR}$, Finland) was used to scrutinize the 96-well plates. Antineoplastic drug vinblastine served as positive control. To determine the viability of treatment, treated and untreated cells were compared [15].

\section{Determination of RBC's Cellular Membrane Protection Activity}

Three milliliters of fresh human blood were subjected to centrifugation for five minutes at $800 \mathrm{rpm}$. The clear supernatant was then cautiously decanted. After washing the sedimented pellets with five milliliters of chilled phosphate buffer saline, further suspension of these cells was carried out in $20 \mathrm{~mL}$ of ice-cold phosphate buffer saline. Cell counting was achieved using hemocytometer. Erythrocyte count for each test was approximately $7.068 \times 10^{8}$ cells $/ \mathrm{mL}$. Reaction mixture containing $20 \mu \mathrm{L}$ of plant sample was further augmented with $180 \mu \mathrm{L}$ of diluted RBC suspension.
One percent Triton X-100 was taken as positive control while PBS as negative control. Incubation of all samples was accomplished at $37^{\circ} \mathrm{C}$ for 35 minutes. Tubes were kept in ice-cold PBS for five minutes and subsequently centrifuged at speed of $1500 \mathrm{rpm}$. A further dilution of $100 \mathrm{~mL}$ supernatant was achieved with $900 \mu \mathrm{L}$ of chilled PBS solution. Each sample including positive and negative control $(200 \mu \mathrm{L})$ was transferred in 96 well microtiter plates. Absorbance was recorded at $576 \mathrm{~nm}$. The following formula was used to determine the $\%$ hemolysis [16].

$$
\% \text { Haemolysis }=\frac{\text { Absorbance }(\text { Sample })}{\text { Absorbance }(\text { Control })} \times 100
$$

\section{Statistical Analysis}

GraphPad prism (Version 8.0) was used for statistical analysis. Values were presented as the arithmetical mean \pm standard deviation (SD). By applying one-way analysis of variance (ANOVA), statistical significance of differences was evaluated. Tukey's multiple comparison test $\mathrm{P} \leq 0.05$ was considered to denote statistical significance.

\section{Results}

\section{In-vitro Antioxidant Activities}

Linear regression equation of gallic acid $(y=0.0104 x+0.174)$ was used for the evaluation of TPC for CA-M extract and its fractions. TPC of CA-M extract and its fractions was found to decrease in following order: $\mathrm{CA}-\mathrm{C}=\mathrm{CA}-\mathrm{H}>\mathrm{CA}-\mathrm{B}>\mathrm{CA}-\mathrm{E}>\mathrm{CA}-\mathrm{Aq}>\mathrm{CA}-\mathrm{M}$. Similarly, TFC was calculated utilizing linear regression equation of quercetin $(y=0.0115 x+0.3002)$. TFC of CA-M extract and its fractions was found to reduce in the following order: $\mathrm{CA}-\mathrm{H}>\mathrm{CA}-\mathrm{C}>\mathrm{CA}-\mathrm{M}>\mathrm{CA}-\mathrm{E}>\mathrm{CA}-$ $\mathrm{B}>\mathrm{CA}-\mathrm{Aq}$. The results are displayed in Fig.1. CA-M extract and its various fractions demonstrate different free radical scavenging activity having $\mathrm{IC}_{50}$ value ranged between $(76.44 \pm 1.50-308 \pm 1.05 \mu \mathrm{g} / \mathrm{mL})$. CA-B fraction exhibited most significant $(\mathrm{p}<0.05)$, lowest $\mathrm{IC}_{50}$ value $(76.44 \pm 1.50 \mu \mathrm{g} / \mathrm{mL})$. Percentage DPPH inhibition of all the extract/fractions/standard displayed the following trend: ascorbic acid $>\mathrm{CA}-\mathrm{B}>\mathrm{CA}-\mathrm{E}>\mathrm{CA}-\mathrm{H}>\mathrm{CA}-\mathrm{C}>\mathrm{CA}-$ $\mathrm{M}>\mathrm{CA}$-Aq. The results are shown in (Table 1)

Fig. 2 reveals the assessment of CA-M extract and its fractions for DNA protective effect against the hydroxyl radicals generated by Fenton's reagent. The results demonstrated the improvements in the level of defense against Fenton's Reagent induced oxidative damage to human DNA following treatments with CA-M extract and its fractions at concentrations of 200 and $400 \mu \mathrm{g} / \mathrm{mL}$. The results indicated that in Lane 12, CA-B fraction at $200 \mu \mathrm{g} / \mathrm{mL}$ was examined to protect the DNA from nicking as compared to all other plant samples. 
Table 1. DPPH scavenging activity of C. ambigua.

\begin{tabular}{|c|c|c|c|c|c|c|c|}
\hline \multirow{2}{*}{$\begin{array}{c}\text { Conc. } \\
\mu \mathrm{g} / \mathrm{mL})\end{array}$} & \multicolumn{9}{|c|}{$\%$ age DPPH inhibition Mean \pm SD } \\
\cline { 2 - 8 } & Ascorbic acid & CA-M & CA-H & CA-C & CA-E & CA-B & CA-Aq \\
\hline 10 & $32.0 \pm 2.65$ & $14.60 \pm 1.51$ & $4.93 \pm 1.01$ & $7.35 \pm 0.74$ & $9.26 \pm 0.89$ & $11.14 \pm 1.79$ & $4.83 \pm 0.68$ \\
\hline 20 & $52.17 \pm 2.75$ & $15.67 \pm 1.53$ & $9.4 \pm 1.51$ & $8.71 \pm 1.46$ & $19.33 \pm 1.76$ & $21.08 \pm 1.89$ & $5.28 \pm 1.59$ \\
\hline 40 & $64.15 \pm 0.79$ & $19.15 \pm 0.78$ & $17.2 \pm 1.71$ & $13.08 \pm 1.39$ & $24.63 \pm 2.13$ & $29.90 \pm 2.16$ & $7.91 \pm 1.14$ \\
\hline 60 & $76.87 \pm 1.21$ & $22.52 \pm 1.76$ & $22.26 \pm 1.63$ & $19.45 \pm 0.58$ & $33.71 \pm 1.46$ & $42.32 \pm 1.55$ & $14.10 .85 \pm$ \\
\hline 80 & $82.33 \pm 2.52$ & $27.85 \pm 1.24$ & $29.10 \pm 1.85$ & $28.14 \pm 1.30$ & $35.89 \pm 2.78$ & $54.23 \pm 1.67$ & $15.15 \pm 1.77$ \\
\hline 100 & $90.15 \pm 2.01$ & $40.15 \pm 1.77$ & $35.49 \pm 2.31$ & $33.14 \pm 1.30$ & $45.04 \pm 2.94$ & $65.09 \pm 1.87$ & $19.04 \pm 1.94$ \\
\hline $\mathrm{IC}_{50} \cdot(\mu \mathrm{g} / \mathrm{mL})$ & $26.22 \pm 1.07^{\mathrm{a}}$ & $168.26 \pm 1.11^{\mathrm{b}}$ & $152.64 \pm 1.52^{\mathrm{c}}$ & $160.26 \pm 1.10^{\mathrm{d}}$ & $121.40 \pm 1.51^{\mathrm{e}}$ & $76.44 \pm 1.50^{\mathrm{f}}$ & $308.18 \pm 1.05^{\mathrm{g}}$ \\
\hline
\end{tabular}

Values displaying same letter $(\mathrm{a}-\mathrm{g})$ in $\mathrm{IC}_{50}$ row have no significant difference ( $\left.\mathrm{p}>0.05\right)$ by Tukey's test at $95 \%$ confidence level

\section{In-vitro $\alpha$-amylase Inhibitory Activity}

Moreover, amongst all fractions and extract, CA-H fraction presented the highest and significant $(p<0.05)$ $\alpha$-amylase inhibition $\left(\mathrm{IC}_{50}=252.2 \pm 1.08\right)$ followed by CA-Aq $\left(\mathrm{IC}_{50}=272 \pm 2.02 \mu \mathrm{g} / \mathrm{mL}\right)$. CA-M extract and its fractions displayed $\mathrm{IC}_{50}$ values in the range of $(252.2 \pm 1.08-2372 \pm 2.51 \mu \mathrm{g} / \mathrm{mL})$. The percentage inhibition of $\alpha$-amylase by CA-M extract and its fractions/standard was found to display the following pattern: acarbose $>$ CA-H $>$ CA-Aq $>$ CA-C $>$ CA-B $>$ CA$\mathrm{E}>\mathrm{CA}-\mathrm{M}$. The percentage inhibition and $\mathrm{IC}_{50}$ values of extract and fractions/standard are mentioned in (Table 2).

\section{Antimicrobial Activity}

Table 3 and 4 unveils the antimicrobial potential of CA-M extract as evaluated by using different strains of bacteria and fungi. CA-M extract at all the studied concentrations i.e., $25 \%, 50 \%$ and $100 \%$, did not show any clear zone of inhibitions against all the investigated bacterial and fungal strains. The results are shown in (Table 3 and 4).

\section{Cytotoxicity Studies}

CA-M extract and fractions were evaluated for cytotoxicity against CCRF-CEM and MDA-MB-231 cell lines at different concentrations $(5 \mu \mathrm{g} / \mathrm{mL}, 10 \mu \mathrm{g} / \mathrm{mL}$,

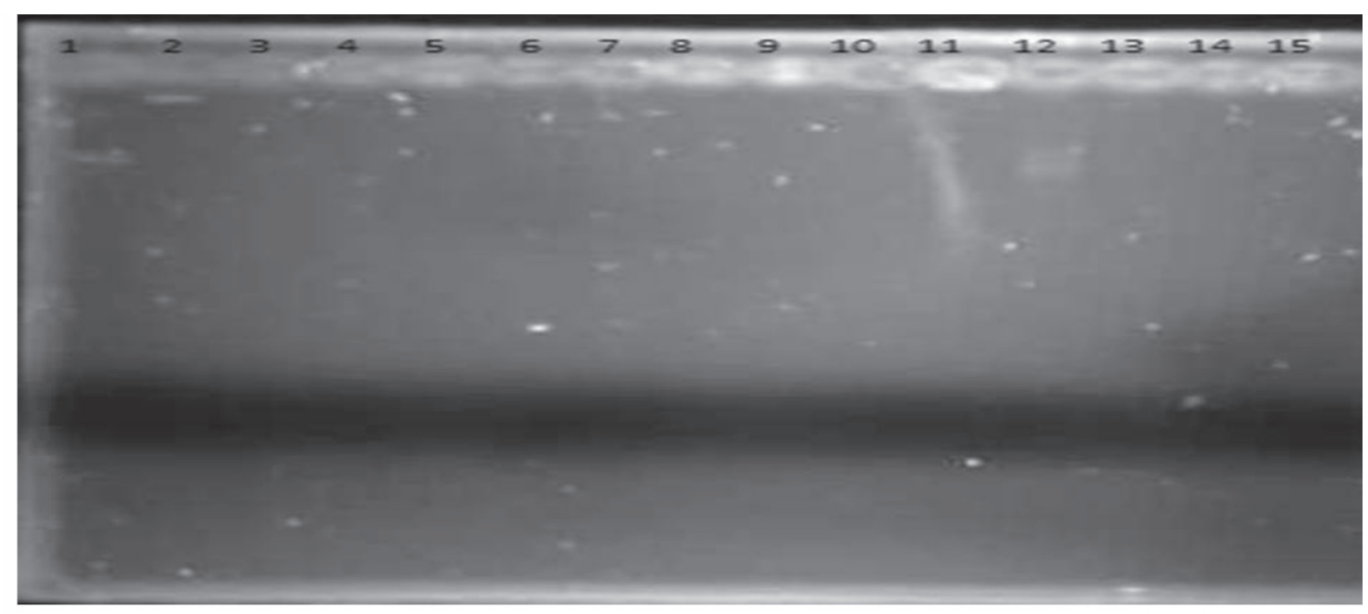

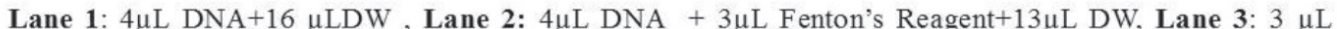
Fenton's Reagent $+17 \mu \mathrm{LDW}$, Lane 4: $4 \mu \mathrm{LDNA}+4 \mu \mathrm{L}$ CA-M $200 \mu \mathrm{g} / \mathrm{mL}+3 \mu \mathrm{LFenton}$ 's reagent $+9 \mu \mathrm{LDW}$, Lane 5: $4 \mu \mathrm{L}$ DNA $+4 \mu \mathrm{L} \mathrm{CA}-\mathrm{M} 400 \mu \mathrm{g} / \mathrm{ml}+3 \mu \mathrm{LFenton}$ 's reagent+9 $\mu \mathrm{L}$ DW, Lane 6: $4 \mu \mathrm{L}$ DNA $+4 \mu \mathrm{L}$ CA$\mathrm{H} 200 \mu \mathrm{g} / \mathrm{mL}+3 \mu \mathrm{LF}$ enton's reagent $+9 \mu \mathrm{L} \mathrm{DW}$, Lane 7: $4 \mu \mathrm{L} \mathrm{DNA}+4 \mu \mathrm{LCA}-\mathrm{H} 400 \mu \mathrm{g} / \mathrm{ml}+3 \mu \mathrm{L}$ Fenton's reagent $+9 \mu \mathrm{L}$ DW, Lane 8: $4 \mu \mathrm{L}$ DNA $+4 \mu \mathrm{L}$ CA-E $200 \mu \mathrm{g} / \mathrm{mL}+3 \mu \mathrm{L}$ Fenton's reagent $+9 \mu \mathrm{L}$ DW, Lane 9: 4 $\mu \mathrm{L}$ DNA $+4 \mu \mathrm{L}$ CA-E $400 \mu \mathrm{g} / \mathrm{ml}+3 \mu \mathrm{L}$ Fenton's reagent $+9 \mu \mathrm{L}$ DW, Lane 10: $4 \mu \mathrm{L}$ DNA $+4 \mu \mathrm{L}$ CA-C $200 \mu \mathrm{g} / \mathrm{mL}+3 \mu \mathrm{L}$ Fenton's reagent $+9 \mu \mathrm{L}$ DW, Lane 11: $4 \mu \mathrm{L}$ DNA $+4 \mu \mathrm{L}$ CA-C $400 \mu \mathrm{g} / \mathrm{mL}+3 \mu \mathrm{L}$ Fenton's reagent $+9 \mu \mathrm{L}$ DW, Lane 12: $4 \mu \mathrm{LDNA}+4 \mu \mathrm{L}$ CA-B $200 \mu \mathrm{g} / \mathrm{ml}+3 \mu \mathrm{L}$ Fenton's reagent $+9 \mu \mathrm{L}$ DW, Lane 13: $4 \mu \mathrm{LDNA}+4 \mu \mathrm{L}$ CA-B $400 \mu \mathrm{g} / \mathrm{ml}+3 \mu \mathrm{L}$ Fenton's reagent $+9 \mu \mathrm{L}$ DW, Lane 14: $4 \mu \mathrm{L}$ DNA $+4 \mu \mathrm{L}$ CA-Aq $200 \mu \mathrm{g} / \mathrm{mL}+3 \mu \mathrm{L}$ Fenton's reagent $+9 \mu \mathrm{L} \mathrm{DW}$, Lane 15: $4 \mu \mathrm{LDNA}+4 \mu \mathrm{L}$ CA-Aq $400 \mu \mathrm{g} / \mathrm{mL}+3 \mu \mathrm{LFenton}$ 's reagent $+9 \mu \mathrm{L} \mathrm{DW}$.

Fig. 2. Electropherogram showing DNA protection effect of CA-M extract and its fractions. 
Table 2. \%age inhibition of $\alpha$-amylase of C. ambigua.

\begin{tabular}{|c|c|c|c|c|c|c|c|}
\hline \multirow{2}{*}{$\begin{array}{c}\text { Conc. } \\
(\mu \mathrm{g} / \mathrm{mL})\end{array}$} & \multicolumn{7}{|c|}{$\%$ age Inhibition of $\alpha$-amylase Mean $\pm \mathrm{SD}$} \\
\cline { 2 - 8 } & Acarbose & CA-M & CA-H & CA-C & CA-E & CA-B & CA-Aq \\
\hline 200 & $46.02 \pm 1.42$ & $12.76 \pm 0.75$ & $45.75 \pm 1.56$ & $35.48 \pm 1.00$ & $35.25 \pm 1.09$ & $26.14 \pm 1.03$ & $46.08 \pm 1.00$ \\
\hline 400 & $62.65 \pm 1.03$ & $13.11 \pm 1.02$ & $60.07 \pm 0.90$ & $53.31 \pm 1.13$ & $40.24 \pm 1.08$ & $46.08 \pm 1.00$ & $58.02 \pm 1.00$ \\
\hline 600 & $75.8 \pm 1.59$ & $18.39 \pm 1.27$ & $64.03 \pm 1.00$ & $56.87 \pm 0.78$ & $43.19 \pm 1.29$ & $54.27 \pm 1.10$ & $61.34 \pm 0.57$ \\
\hline 800 & $82.37 \pm 0.82$ & $22.10 \pm 0.96$ & $76.94 \pm 0.59$ & $58.20 \pm 0.72$ & $45.12 \pm 1.02$ & $57.13 \pm 1.03$ & $77.09 \pm 1.01$ \\
\hline 1000 & $93.41 \pm 0.65$ & $25.37 \pm 0.79$ & $83.04 \pm 1.00$ & $59.05 \pm 0.92$ & $52.00 \pm 1.00$ & $62.08 \pm 1.00$ & $82.16 \pm 1.04$ \\
\hline $\mathrm{IC}_{50}(\mu \mathrm{g} / \mathrm{mL})$ & $207 \pm 1.00^{\mathrm{a}}$ & $2372 \pm 2.51^{\mathrm{b}}$ & $252.2 \pm 1.08^{\mathrm{c}}$ & $305 \pm 1.53^{\mathrm{d}}$ & $940 \pm 1.76^{\mathrm{e}}$ & $615 \pm 1.28^{\mathrm{f}}$ & $272 \pm 2.02^{\mathrm{g}}$ \\
\hline
\end{tabular}

Values displaying same letter (a-g) in $\mathrm{IC}_{50}$ row have no significant difference $(\mathrm{p}>0.05)$ by Tukey's test at $95 \%$ confidence level

Table 3. Antibacterial activity of C. ambigua.

\begin{tabular}{|c|c|c|c|c|c|}
\hline \multirow{2}{*}{ Samples } & \multicolumn{5}{|c|}{ Zone of inhibitions (mm) Mean \pm SD } \\
\cline { 2 - 6 } & E. coli & P. aeruginosa & S. typhimurium & S. aureus & S. epidermidis \\
\hline Negative Control & $0 \pm 0$ & $0 \pm 0$ & $0 \pm 0$ & $0 \pm 0$ & $0 \pm 0$ \\
\hline Positive Control & $27.73 \pm 1.42$ & $24.73 \pm 1.17$ & $22 \pm 1.32$ & $23.07 \pm 1.90$ & $23.87 \pm 1.56$ \\
\hline CA-M 25\% & $0 \pm 0$ & $0 \pm 0$ & $0 \pm 0$ & $0 \pm 0$ & $0 \pm 0$ \\
\hline CA-M 50\% & $0 \pm 0$ & $0 \pm 0$ & $0 \pm 0$ & $0 \pm 0$ & $0 \pm 0$ \\
\hline CA-M100\% & $0 \pm 0$ & $0 \pm 0$ & $0 \pm 0$ & $0 \pm 0$ & $0 \pm 0$ \\
\hline
\end{tabular}

and $50 \mu \mathrm{g} / \mathrm{mL}$ ). The results obtained manifested that $C$. ambigua possesses dose dependent inhibitory action on cell growth. The results demonstrated that CCRF-CEM cell lines are more sensitive to $C$. ambigua at higher concentration as compared to MDA-MB-231 cell lines. CA-H, CA-C, CA-E and CA-B fractions at $50 \mu \mathrm{g} / \mathrm{mL}$, showed the significant $(p<0.05)$ cytotoxicity against CCRF-CEM cell lines. Whereas CA-H and CA-C fractions at $50 \mu \mathrm{g} / \mathrm{mL}$ showed significant $(\mathrm{p}<0.05)$ results against MDA-MB-231 cell lines. The findings of all the fractions of $C$. ambigua and extract/standard are depicted in Table 5. Fig. 3 unveils the toxic effects of CA-M extract and fractions at different doses i.e., 250, 500, and $1000 \mu \mathrm{g} / \mathrm{mL}$, against human RBC's

Table 4. Antifungal activity of C. ambigua.

\begin{tabular}{|c|c|c|}
\hline \multirow{2}{*}{ Samples } & \multicolumn{2}{|c|}{$\begin{array}{c}\text { Zone of inhibitions (mm) } \\
\text { Mean } \pm \text { SD }\end{array}$} \\
\cline { 2 - 3 } & C. albicans & S. cerevisiae \\
\hline Negative Control & $0 \pm 0$ & $0 \pm 0$ \\
\hline Positive Control & $26.13 \pm 0.91$ & $24.4 \pm 0.66$ \\
\hline CA-M 25\% & $0 \pm 0$ & $0 \pm 0$ \\
\hline CA-M 50\% & $0 \pm 0$ & $0 \pm 0$ \\
\hline CA-M 100\% & $0 \pm 0$ & $0 \pm 0$ \\
\hline
\end{tabular}

were evaluated. Hemolytic activity of all the fractions and extract of $C$. ambigua were in the range between $(2.31 \%-7.77 \%)$. The findings from this study, however, showed a high safety profile of the plant at all tested doses.

\section{Discussion}

The present study was intended to elucidate medicinal importance of $C$. ambigua by employing CA-M extract and its fractions in various in vitro pharmacological assays. The findings obtained through TFC and TPC suggest that the plant encompass substantial profusion of flavonoid and phenolic components. Flavonoids are phenolic compounds that are highly effective antioxidants [17]. They are essential for normal growth and provide protection against infection and injury to the plant. In our study, TPC and TFC of CA-M extract and its fractions were evaluated using FC reagent method that measures the redox properties of the polyphenols [18].

The exploration of novel antioxidants belonging to plant origin has amplified because these manifests an essential part in protective effects of plantbased treatments. Antioxidant potential of CA-M extract and its fractions were investigated through DPPH scavenging method. The method is based on reduction of alcoholic DPPH solution in the presence 
Table 5. Cell proliferation and viability response of C.ambigua by XTT assay.

\begin{tabular}{|c|c|c|}
\hline Sample Name & $\%$ age of cell viability*(CCRF-CEM) Mean \pm SD & $\%$ age of cell viability*(MDA-MB-231) Mean \pm SD \\
\hline Control & $100 \pm 1.548^{\mathrm{a}}$ & $100 \pm 0.748^{\mathrm{a}}$ \\
\hline Vinblastine & $0.578 \pm 0.247^{\mathrm{b}}$ & $18.271 \pm 1.056^{\mathrm{b}}$ \\
\hline CA-M $5 \mu \mathrm{g} / \mathrm{mL}$ & $91.604 \pm 2.404^{\mathrm{c}}$ & $84.7999 \pm 1.863^{\mathrm{c}}$ \\
\hline CA-M $10 \mu \mathrm{g} / \mathrm{mL}$ & $81.740 \pm 2.154^{\mathrm{d}}$ & $80.374 \pm 1.388^{\mathrm{c}, \mathrm{d}}$ \\
\hline CA-M $50 \mu \mathrm{g} / \mathrm{mL}$ & $29.842 \pm 3.132^{\mathrm{e}}$ & $79.940 \pm 1.463^{\mathrm{c}, \mathrm{d}}$ \\
\hline CA-H $5 \mu \mathrm{g} / \mathrm{mL}$ & $96.468 \pm 2.922^{\mathrm{a}, \mathrm{c}}$ & $89.598 \pm 1.525^{\mathrm{a}, \mathrm{c}, \mathrm{d}}$ \\
\hline CA-H $10 \mu \mathrm{g} / \mathrm{mL}$ & $83.833 \pm 2.210^{\mathrm{d}}$ & $89.081 \pm 1.977^{\mathrm{a}, \mathrm{c}, \mathrm{d}, \mathrm{e}}$ \\
\hline CA-H $50 \mu \mathrm{g} / \mathrm{mL}$ & $7.533 \pm 0.430^{\mathrm{f}}$ & $47.327 \pm 13.462^{\mathrm{f}}$ \\
\hline CA-C $5 \mu \mathrm{g} / \mathrm{mL}$ & $90.870 \pm 1.637^{\mathrm{c}}$ & $76.900 \pm 1.596^{\mathrm{c}, \mathrm{d}, \mathrm{g}}$ \\
\hline CA-C $10 \mu \mathrm{g} / \mathrm{mL}$ & $74.241 \pm 1.785^{\mathrm{g}}$ & $77.996 \pm 1.864^{\mathrm{c}, \mathrm{d}, \mathrm{g}}$ \\
\hline CA-C $50 \mu \mathrm{g} / \mathrm{mL}$ & $13.321 \pm 0.819^{\mathrm{f}}$ & $54.751 \pm 2.595^{\mathrm{f}}$ \\
\hline CA-E $5 \mu \mathrm{g} / \mathrm{mL}$ & $92.691 \pm 1.650^{\mathrm{c}}$ & $81.594 \pm 1.596^{\mathrm{c}, \mathrm{d}, \mathrm{eg}}$ \\
\hline CA-E $10 \mu \mathrm{g} / \mathrm{mL}$ & $87.120 \pm 0.627^{\mathrm{c}, \mathrm{d}}$ & $76.651 \pm 2.529^{\mathrm{c}, \mathrm{d}, \mathrm{g}}$ \\
\hline CA-E $50 \mu \mathrm{g} / \mathrm{mL}$ & $38.265 \pm 4.330^{\mathrm{h}}$ & $78.534 \pm 2.325^{\mathrm{c}, \mathrm{d}, \mathrm{e}, \mathrm{g}}$ \\
\hline CA-B $5 \mu \mathrm{g} / \mathrm{mL}$ & $98.261 \pm 3.345^{\mathrm{a}, \mathrm{c}}$ & $94.602 \pm 1.947^{\mathrm{a}, \mathrm{c}, \mathrm{e}}$ \\
\hline CA-B $10 \mu \mathrm{g} / \mathrm{mL}$ & $92.990 \pm 2.442^{\mathrm{c}}$ & $92.514 \pm 2.862^{\mathrm{a}, \mathrm{c}, \mathrm{e}}$ \\
\hline CA-B $50 \mu \mathrm{g} / \mathrm{mL}$ & $26.146 \pm 1.769^{\mathrm{e}}$ & $89.846 \pm 1.958^{\mathrm{a}, \mathrm{c}, \mathrm{d}, \mathrm{e}}$ \\
\hline CA-Aq $5 \mu \mathrm{g} / \mathrm{mL}$ & $101.526 \pm 1.929^{\mathrm{a}}$ & $98.759 \pm 2.192^{\mathrm{a}, \mathrm{e}}$ \\
\hline CA-Aq $10 \mu \mathrm{g} / \mathrm{mL}$ & $103.532 \pm 2.165^{\mathrm{a}}$ & $98.511 \pm 1.129^{\mathrm{a}, \mathrm{e}}$ \\
\hline CA-Aq $50 \mu \mathrm{g} / \mathrm{mL}$ & $95.163 \pm 2.022^{\mathrm{a}, \mathrm{c}}$ & $95.368 \pm 2.192^{\mathrm{a}, \mathrm{c}, \mathrm{e}}$ \\
\hline
\end{tabular}

Values displaying same letter (a-g) in same column do not show significant difference $(\mathrm{p}>0.05)$ by Tukey's test at $95 \%$ confidence level

of an antioxidant which can donate hydrogen due to the formation of non- radical form DPPH-H [19]. In the current study, the most significant $(\mathrm{p}<0.05)$ percentage DPPH inhibition was established by CA-B fraction $\left(\mathrm{IC}_{50}=76.44 \pm 1.50 \mu \mathrm{g} / \mathrm{mL}\right)$ followed by CA-E fraction $\left(\mathrm{IC}_{50}=121.40 \pm 1.51 \mu \mathrm{g} / \mathrm{mL}\right)$ and the

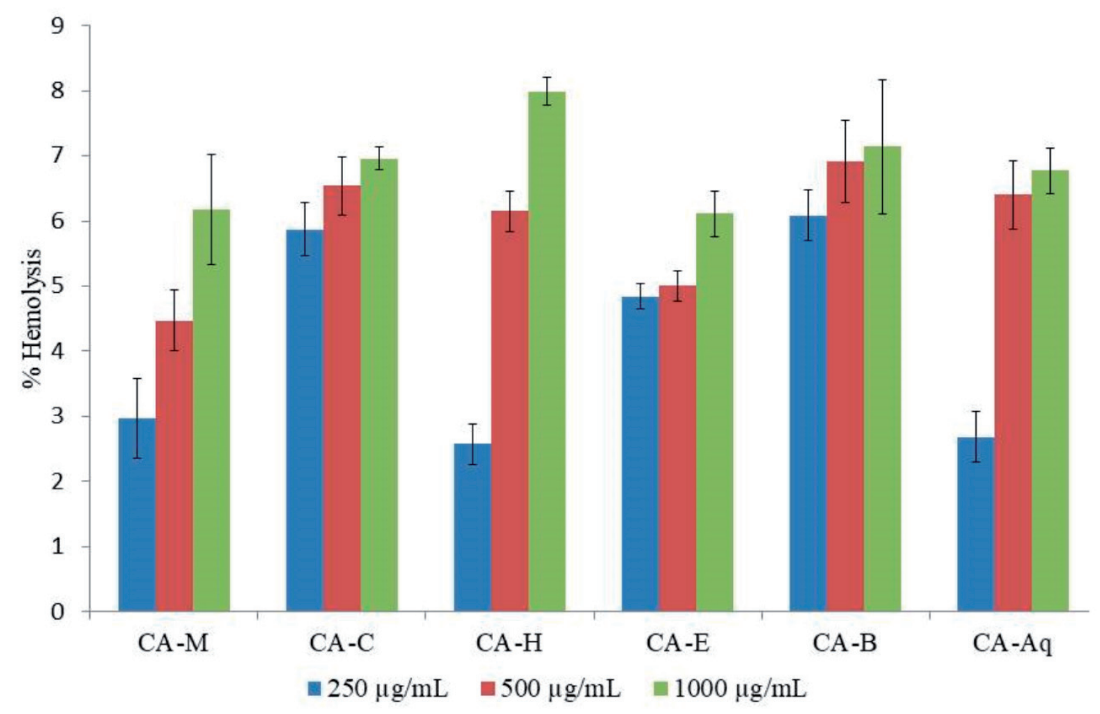

Fig. 3. Hemolytic activity of CA-M extract and its fractions against human erythrocytes. 
results are consistent with the previous study in which four different extracts of C. ambigua plant (methanol, ethyl-acetate, n-hexane and aqueous) were evaluated for antioxidant potential through DPPH assay and the highest DPPH inhibition was spotted in ethyl-acetate plant extract $(83.32 \pm 6.22 \mathrm{mgTE} / \mathrm{g})$ [3].

Plant fractions and extracts (having protective DNA effect) to the DNA containing Fenton's reagent reduce the formation of double stranded as well as single stranded nicked and linear DNA and therefore, sustain supercoiled DNA by adopting hydrogen abstraction mechanism [12]. Among all the tested plant samples, CA-B fraction at $200 \mu \mathrm{g} / \mathrm{mL}$ (Lane 12) was observed to protect the DNA from nicking. In the study, the results of in vitro antioxidant assay (DPPH) also indicated the maximum antioxidant potential of CA-B fraction among all the test samples. Therefore, it can be concluded that the DNA protection behavior of the sample may be credited to the higher concentrations of flavonoid and phenolic constituents, as well as their ability to scavenge free radicals and oxidative products.

Most of the medicinal agents work by the inhibition of specific enzymes. In the present study, enzyme inhibition of CA-M extract and its fractions were tested against $\alpha$-amylase. Inhibitors of $\alpha$-amylase are effective in regulating hyperglycemia as these slow the absorption of carbohydrates, consequently decreasing the amount of postprandial glucose level of blood in diabetic patients [20]. In the previously published research, four different extracts of $C$. ambigua (aqueous, methanol, n-hexane and ethylacetate) were tested against $\alpha$-amylase. The $n$-hexane extract was reported to have maximum inhibition of $\alpha$-amylase $(0.81 \pm 0.02 \mathrm{mmol} / \mathrm{ACAE} / \mathrm{g}$ extract $)$ [3]. The conclusions of our study are in agreement with the previous report according to which among all the tested fractions and extract of C. ambigua, the most significant $(p<0.05) \alpha$-amylase enzyme inhibition was displayed by CA-H fraction $\left(\mathrm{IC}_{50}=252.2 \pm 1.08 \mu \mathrm{g} / \mathrm{mL}\right)$. The highest concentration of flavonoid content in $\mathrm{CA}-\mathrm{H}$ fraction may be attributed to the antidiabetic potential of CA-H fraction of the plant. In a similar way, presence of flavonoids possessing hypoglycemic properties was also reported in C. arborescens [21].

Although antimicrobial potential of Caragana genus has already been reported in the literature yet, according to our knowledge, a comprehensive study on the topic for C. ambigua is still not published. C. jubata was noted to have moderate antimicrobial activity against the tested strains of bacteria and fungi [22]. Similarly, 3-O- methyl kaempferol unearthed strong antibacterial activity from the ethyl-acetate fraction of crude ethanolic extract of C. leucophloea [23]. However, in our study, CA-M extract did not show any antimicrobial results at all the tested doses. Thus, it can be inferred that $C$. ambigua lacks antimicrobial potential against the tested strains and may not be exploited as antimicrobial agent against the tested bacterial and fungal infectious diseases.
The tetrazolium salt, XTT is of particular use in the quantification of viable cells. XTT (sodium 3-[1-(phenyl-amino-carbonyl) - 3,4tetrazolium] - bis(4methoxy-6-nitro) benzene sulfonic acid hydrate) a second generation of tetrazolium salt derivative, is a colorless or pale-yellow compound that turns into bright orange when it is reduced to form a water-soluble formazan derivative by mitochondrial oxidoreductases, released by viable cells [24]. CA-M extract and its fractions were subjected to XTT assay for scrutinizing the proliferation response against CCRF-CEM and MDA-MB-231 cell lines. CCRF-CEM cell line was found to be more sensitive as compared to MDAMB-231 cancer cell lines. Amongst all the extract and fractions, CA-H revealed maximum inhibition $(7.533 \pm 0.430 \%)$ and $(47.327 \pm 13.462 \%)$ at $50 \mu \mathrm{g} / \mathrm{mL}$ against CCRF-CEM and MDA-MB-231 cell lines, respectively. C. ambigua indicated a dose dependent inhibitory effect on cell growth which might be attributed to the presence of polyphenolic compounds. Many polyphenolic compounds like gingerol, sphalleroside A, psoralidin oxide, kaempferide and 2,3-Dehydrokievitone have already been reported in $C$. ambigua [3]. However, to the finest of our information, this is the first report in terms of cytotoxic potential of C. ambigua against these cancer cell lines.

The stability of erythrocytic membrane is considered a good predictor of the impact of various in vitro studies conducted by using various compounds for cytotoxicity screening [16]. The hemolytic activity of CA-M extract and its fractions was found to be in the range between (2.31\%-7.77\%). Hemolytic potential of plant extract or fractions below $10 \%$ is considered safe to be utilized for therapeutic purposes [25]. Concisely, C. ambigua may be considered safe to use as a source of potential medications for humans.

\section{Conclusion}

The present study offered scientific evidence for the antioxidant, antidiabetic, cytotoxic and antimicrobial potential of C. ambigua and provides supportive data for the future research that will contribute to its use in oxidative stress related disorders like diabetes and cancer. However, no significant antimicrobial potential was observed against the tested microbes. Hemolytic activity concluded that $C$. ambigua is harmless towards human erythrocytes and thus may be used in pharmaceuticals as a therapeutic source for the production of beneficial drugs against various human diseases.

\section{Acknowledgments}

Special thanks to The Higher Education Commission of Pakistan for Author's PhD scholarship. 


\section{Conflict of Interest}

The authors declare no conflict of interest.

\section{References}

1. KHAN R., FATIMA I., AHMAD N., MALIK A. Caragin, a new isoflavone from Caragana conferta. J. Asian Nat. Prod. Res. 10 (9), 823, 2008.

2. MENG Q., NIU Y., NIU X., ROUBIN R.H., HANRAHAN J.R. Ethnobotany, phytochemistry and pharmacology of the genus caragana used in traditional Chinese medicine. J. Ethnopharmacol. 124 (3), 350, 2009.

3. KHAN S., NAZIR M., RAIZ N., SALEEM M., ZENGIN G., FAZAL G., SALEEM H., MUKHTAR M., TOUSIF M.I., TAREEN R.B. Phytochemical profiling, In vitro biological properties and in silico studies on Caragana ambigua stocks (Fabaceae): A comprehensive approach. Ind. Crop. Prod. 131, 117, 2019.

4. ZAIN-UL-ABIDIN S., KHAN R., AHMAD M., BHATTI M.Z., ZAFAR M., SAEED A., KHAN N. Ethnobotanical survey of highly effective medicinal plants and phytotherapies to treat diabetes mellitus ii in south-west Pakistan. Indian J. Tradit. Knowl. 17, 682, 2018.

5. SARANGZAI A.M., AHMED A., LAGHARI S.K. Traditional uses of some useful medicinal plants of Ziarat district Balochistan, Pakistan. J. Biol. 3 (1), 101, 2013.

6. AHMAD K., PIERONI A. Folk knowledge of wild food plants among the tribal communities of Thakht-e-Sulaiman Hills, North-West Pakistan. J. Ethnobiol. Ethnomedicine. 12 (1), $1,2016$.

7. KAYANI S.A., MASOOD A., ACHAKZAI A.K.K., ANBREEN S. Distribution of secondary metabolites in plants of Quetta-Balochistan. J. Bot. 39 (4), 1173, 2007.

8. JIE Y., ZHAO H., SUN X., LV X., ZHANG Z., ZHANG B. Isolation of antioxidative peptide from the protein hydrolysate of Caragana ambigua seeds and its mechanism for retarding lipid auto-oxidation. J. Sci. Food. Agric. 99 (6), 3078, 2019.

9. SAEED N., KHAN M.R., SHABBIR M. Antioxidant Activity, Total phenolic and total flavonoid contents of whole plant extracts Torilis leptophylla L. BMC Compl. Alternative Med. 12 (1), 1, 2012.

10. CHANDRA S., KHAN S., AVULA B., LATA H., YANG M.H., ELSOHLY M.A., KHAN I.A. Assessment of total phenolic and flavonoid content, antioxidant properties, and yield of aeroponically and conventionally grown leafy vegetables and fruit crops: A comparative study. Evid. Based Complement. Alternat. 2014, 1, 2014.

11. SOARE J.R., DINIS T.C., CUNHA A. ., ALMEIDA L. Antioxidant activities of some extracts of Thymus zygis. Free Redic. Res. 26 (5), 469, 1997.

12. KAUR R., ARORA S., SINGH B. Antioxidant activity of the phenol rich fractions of leaves of Chukrasia tabularis A. Juss. Bioresour. Technol. 99 (16), 7692, 2008.

13. WICKRAMARATNE M.N., PUNCHIHEWA J., WICKRAMARATNE D. In-vitro alpha amylase inhibitory activity of the leaf extracts of Adenanthera pavonina. BMC compl. Alternative Med. 16 (1), 1, 2016.

14. BHALODIA N.R., SHUKLA V.J. Antibacterial and antifungal activities from leaf extracts of Cassia fistula 1.: An Ethnomedicinal plant. J. Adv. Phar. Technol. 2 (2), 104, 2011.

15. KRETSCHMER N., RINNER B., DEUTSCH A.J., LOHBERGER B., KNAUSZ H., KUNERT O., BLUNDER M., BOECHZELT H., SCHAIDER H., BAUER R. Naphthoquinones from Onosma paniculata induce cellcycle arrest and apoptosis in melanoma cells. J. Nat. Prod. 75 (5), 865, 2012.

16. ZUBAIR M., RIZWAN K., RASHID U., SAEED R., SAEED A. A., RASOOL N., RIAZ M. GC/MS profiling, In vitro antioxidant, antimicrobial and haemolytic activities of Smilax macrophylla leaves. Arab. J. Chem. 10, S1460, 2017.

17. YANISHLIEVA N.V., MARINOVA E.M. Stabilisation of edible oils with natural antioxidants. J. Lipid. Sci. Technol. 103 (11), 752, 2001.

18. OKONOGI S., DUANGRAT C., ANUCHPREEDA S., TACHAKITTIRUNGROD S., CHOWWANAPOONPOHN S. Comparison of antioxidant capacities and cytotoxicities of certain fruit peels. Food Chem. 103 (3), 839, 2007.

19. GÜLÇIN I., ELMASTAŞ M., ABOUL-ENEIN H. Determination of antioxidant and radical scavenging activity of Basil (Ocimum basilicum L. Family Lamiaceae) assayed by different methodologies. Phytother. Res. 21 (4), 354, 2007.

20. TELAGARI M., HULLATTI K. In-vitro $\alpha$-amylase and $\alpha$-glucosidase inhibitory activity of Adiantum caudatum Linn. and Celosia argentea Linn. Extracts and fractions. Indian J. Pharmacol. 47 (4), 425, 2015.

21. MANDAL R., SIVA B., BABU V.P., BABU K.S., JAGADEESH B., RANJIT R., SHRESTHA K., GEWALI M.B. Novel cycloartane triterpenoids from the Nepal native plant Caragana sukiensis. Med. Chem. Lett. 25 (22), 5168, 2015.

22. KAKORIN P., FATEEVA T., TERESHKINA O., PEROVA I., RAMENSKAYA G., SOLOGOVA S., ELLER K. Antimicrobial activity of lyophilized aqueous extract from Caragana Jubata (Pall.) Poir. Pharm. Chem. J. 54 (3), 290, 2020.

23. GAO H., LUO C., WANG L., WANG J., ZHENG B., PENG Y., ZHOU L. Preparative separation of 3-O-methylkaempferol from Caragana leucophloea by high-speed counter-current chromatography and its antimicrobial activity. J. Med. Plant. Res. 6 (11), 2081, 2012.

24. CHANDA S., NAGANI K. In vitro and In vivo methods for anticancer activity evaluation and some Indian medicinal plants possessing anticancer properties: an overview. J. Pharmacogn. Phytochem. 2 (2), 140, 2013.

25. RASOOL S., KHAN F. Z., AHMAD M. Evaluation of anticonvulsant, antimicrobial and hemolytic activity of Aitchisonia rosea. Bangladesh j. Pharmacol. 10 (4), 980, 2015. 